Article

\title{
Trade-Offs between Urban Green Space and Densification: Balancing Outdoor Thermal Comfort, Mobility, and Housing Demand
}

\author{
Sabrina Erlwein * and Stephan Pauleit \\ Chair for Strategic Landscape Planning and Management, Technical University of Munich, 85354 Freising, Germany; \\ E-Mails: sabrina.erlwein@tum.de (S.E.), pauleit@tum.de (S.P.) \\ * Corresponding author
}

Submitted: 15 July 2020 | Accepted: 23 September 2020 | Published: 26 January 2021

\begin{abstract}
Urban green spaces reduce elevated urban temperature through evaporative cooling and shading and are thus promoted as nature-based solutions to enhance urban climates. However, in growing cities, the supply of urban green space often conflicts with increasing housing demand. This study investigates the interplay of densification and the availability of green space and its impact on human heat stress in summer. For the case of an open-midrise (local climate zone 5) urban redevelopment site in Munich, eight densification scenarios were elaborated with city planners and evaluated by microscale simulations in ENVI-met. The chosen scenarios consider varying building heights, different types of densification, amount of vegetation and parking space regulations. The preservation of existing trees has the greatest impact on the physical equivalent temperature (PET). Construction of underground car parking results in the removal of the tree population. Loss of all the existing trees due to parking space consumption leads to an average daytime PET increase of $5^{\circ} \mathrm{C}$ compared to the current situation. If the parking space requirement is halved, the increase in PET can be reduced to $1.3^{\circ} \mathrm{C}-1.7^{\circ} \mathrm{C}$ in all scenarios. The addition of buildings leads to a higher gain in living space than the addition of floors, but night-time thermal comfort is affected by poor ventilation if fresh air circulation is blocked. The protection of mature trees in urban redevelopment strategies will become more relevant in the changing climate. Alternative mobility strategies could help to reduce trade-offs between densification and urban greening.
\end{abstract}

\section{Keywords}

densification; ENVI-met simulations; green infrastructure; outdoor thermal comfort

\section{Issue}

This article is part of the issue "Urban Planning and Green Infrastructure" edited by Paul Osmond (University of New South Wales, Australia) and Sara Wilkinson (University of Technology Sydney, Australia).

(C) 2021 by the authors; licensee Cogitatio (Lisbon, Portugal). This article is licensed under a Creative Commons Attribution 4.0 International License (CC BY).

\section{Introduction}

In the past decade, green and blue spaces in cities have been promoted as no or low regret adaptation measures to climate change (European Commission, 2016). Bodies of water and vegetated areas regulate air temperature $\left(T_{a}\right)$ and radiative heat load and thus improve outdoor human thermal comfort through evaporative cooling and shading (Bowler, Buyung-Ali, Knight, \& Pullin, 2010). Among these, trees are the most effective in reducing incoming shortwave radiation (Erell, 2017; Zölch, Maderspacher, Wamsler, \& Pauleit, 2016).
Dense, foliated tree crowns reduce the transmissivity of direct solar radiation to $1 \%-5 \%$ (Konarska, Lindberg, Larsson, Thorsson, \& Holmer, 2014), reducing daytime $\mathrm{T}_{\mathrm{a}}$ by up to $3^{\circ} \mathrm{C}$, the mean radiant temperature by up to $37^{\circ} \mathrm{C}$ and the physical equivalent temperature (PET) directly beneath the tree crown by up to $16^{\circ} \mathrm{C}$ (Lee, Mayer, \& Kuttler, 2020). However, ongoing urbanisation and population growth lead to high pressure on open spaces in cities. Therefore, urban areas undergoing densification by the addition of buildings or the increase in the size of existing buildings often exhibit a lack of urban green space (Haaland \& van den Bosch, 2015). 
Reduced amounts of green space, an increase of impervious surfaces, altered albedo and geometry are all contributing factors to the Urban Heat Island phenomena (Oke, 1982). Such infill development is likely to further increase urban heat load, exacerbating existing outdoor heat stress (Emmanuel \& Steemers, 2018).

Confronted with the need to meet the housing demand on one hand and the challenge to adapt cities to climate change on the other, city planners require information about the effects of densification on urban microclimate, green space availability and its ecosystem services. The factors that influence urban climate and urban heat have been studied from the city level (e.g., Akbari \& Kolokotsa, 2016; Deilami, Kamruzzaman, \& Liu, 2018) to the neighbourhood scale (Pacifici, Marins, Catto, Rama, \& Lamour, 2017) and single urban facets (e.g., Jamei \& Rajagopalan, 2018; Lee et al., 2020). While climate adaptation planning needs to adopt a multiscale perspective to address the Urban Heat Island as well as local thermal hotspots (Demuzere et al., 2014), the microclimatic level is the reference scale for outdoor human thermal comfort investigations (Hirashima, Katzschner, Ferreira, Assis, \& Katzschner, 2018; Mayer \& Höppe, 1987). The urban layout and geometry, as well as abundance of vegetation, are some of the most important parameters governing urban microclimate and outdoor thermal comfort (Erell, Pearlmutter, \& Williamson, 2011; Jamei, Rajagopalan, Seyedmahmoudian, \& Jamei, 2016). Altered aspect ratios and sky view factors affect the shortand long-wave radiation as well as the wind speed (Erell et al., 2011). For instance, higher aspect ratios due to taller buildings are likely to lead to lower daytime and higher night-time air temperature (Jamei et al., 2016). Wide $\mathrm{E}-\mathrm{W}$ oriented streets are more prone to thermal discomfort than narrow and $\mathrm{N}-\mathrm{S}$ oriented street canyons due to longer times of solar exposure (Ali-Toudert \& Mayer, 2006); thus vegetation plays an important role, especially for E-W oriented streets (Sanusi, Johnstone, May, \& Livesley, 2016).

Differing from these studies that concentrate on single urban street canyons, other investigations have compared city quarters with different amounts of vegetation, built area coverages and building heights (Yahia, Johansson, Thorsson, Lindberg, \& Rasmussen, 2018) or have altered these characteristics for a specific setting to study their micrometeorological impacts (Perini \& Magliocco, 2014). Yahia et al. (2018) found the strongest relationship ( $\left.R^{2} 0.97\right)$ to be between sky view factor and PET at 2 pm, and shading to be more important than ventilation. Simultaneously increasing the building height and the green coverage provided the best thermal comfort for pedestrians (Lee et al., 2020; Perini \& Magliocco, 2014). In this regard, increasing building height is preferred over increasing built area coverage (Emmanuel \& Steemers, 2018); however, in these studies green coverage was rather treated as a quantitative parameter with disregard of the impact of densification on the qualities of the existing vegetation. Investigating nature-based solutions in a densely built-up area, Zölch et al. (2016) emphasised that the qualities of urban greening and the placement of street trees have a decisive influence on outdoor thermal comfort. The effects of densification on existing vegetation were not investigated. In their review of challenges and strategies for densifying cities, Haaland and van den Bosch (2015) noted that there is a lack of studies that consider the interplay of urban infill and the qualities of the existing green space, as well as the planning advice to deal with both.

In reference to the microscale, the aim of this study is therefore to answer the following research questions: i) How is urban green space (especially urban trees) affected by densification and what are the consequences for human heat stress? ii) How can the tradeoffs between densification and greening be effectively minimised? Based on an actual planning case in the city of Munich (Germany), we compare different development scenarios to quantify the effects of densification on the existing green space and human heat stress. In a first step, we derive key parameters for the development of realistic densification scenarios by planning in exchange with city planners. Second, we create densification scenarios that portray different planning options for the open midrise redevelopment area. Finally, micrometeorological simulations (ENVI-met model) are carried out to compare the densification alternatives with the current situation and to discuss the implications for urban planning.

\section{Study Area}

Munich, located in the south of Germany $\left(48^{\circ} 8^{\prime} \mathrm{N}\right.$, $11^{\circ} 24^{\prime} \mathrm{E}$, elevation $519 \mathrm{~m}$ a.s.I.), is one of the fastestgrowing cities in Germany and is expected to reach 1.85 million inhabitants by 2035 (Landeshauptstadt München, 2011). With an annual average $T_{a}$ of $9.7^{\circ} \mathrm{C}$ and an average precipitation of $944 \mathrm{~mm}$ (reference period 1981-2010; German Meteorological Service, 2018), Munich's climate corresponds to the Cfb category of the Köppen-Geiger classification. The characteristics of the city's climate include warm summers, an absence of dry seasons and highest precipitation rates during the summertime (Mühlbacher, Koßmann, Sedlmaier, \& Winderlich, 2020).

While housing demand in Munich is high (according to an estimate, there is an annual requirement for the building of 8,500 flats per year; Landeshauptstadt München, 2011), the potential for the development of new residential areas outside the city and through the conversion of disused land has become scarce. One of the city's strategies for dealing with this scarcity is "qualified densification" in the stock (Landeshauptstadt München, 2011). This is especially the case with housing estates from the 1950 s to the 1980 s, which account for a quarter of all residential areas in Munich and offer great potential for gaining new residential space. The urban redevelopment area in Munich's city district, Moosach, is characterised by free-standing multistorey blocks from 
the 1950s. Free-standing multistorey blocks have a high potential for densification due to the presence of generous green spaces and, often, uniform ownership structures, that simplify planning and communication processes. Furthermore these multistorey blocks represent one of the most common building types in Munich (Pauleit \& Duhme, 2000) and, more generally, in German cities (Zentrum für Stadtnatur und Klimaanpassung, 2017). The study area comprises 10-row buildings with pitched roofs of $14 \mathrm{~m}$ in height (four floors including the attic floor; Figure 1). There are large green spaces between the building rows - some with a high tree cover, some rather open-that result in a vegetation cover of $50 \%$. Thus, the area can be characterised as local climate zone 5 (open midrise). Local climate zones represent universal climate-based classifications of urban and rural sites that share similar characteristics regarding surface cover, building structure, materials and human activity (Stewart \& Oke, 2012).

A particular challenge for developing green and dense city quarters in Munich lies in providing sufficient car parking space. According to Bavarian planning regulations, one parking space has to be provided for each residential unit (Art. 47 BayBO). Based on a resolution by the City Council of Munich, this ratio can be reduced when access to public transport and local amenities is sufficient or in the case of subsidised residential construc- tion. To do so, a profound mobility concept has to be provided, in which required criteria and alternative mobility solutions have to be stated. Reductions below a 0.8 ratio require extensive compensation measures, while 0.3 represents the maximum reduction ratio (Landeshauptstadt München, 2020).

\section{Methodology}

\subsection{Development of Densification Scenarios}

To gain insights in current planning policy into Munich and to derive realistic densification scenarios, we investigated all the local plans that have come into force in recent years (1 January 2014-28 March 2019). Local plans are legally binding planning instruments that concretise the possible use of a certain area and provide guidelines for possible structural development. Since inner-city development and residential areas were particularly of interest for this study, we excluded all the local plans relating to outdoor, special and industrial areas from further analysis ( 25 out of 60 plans). The remaining 35 plans were categorised regarding their location, type of development, permissible floor space and floor area, building height, planned residential units and plan layouts. Of further interest were the regulations dealing with parking space and green space provision.
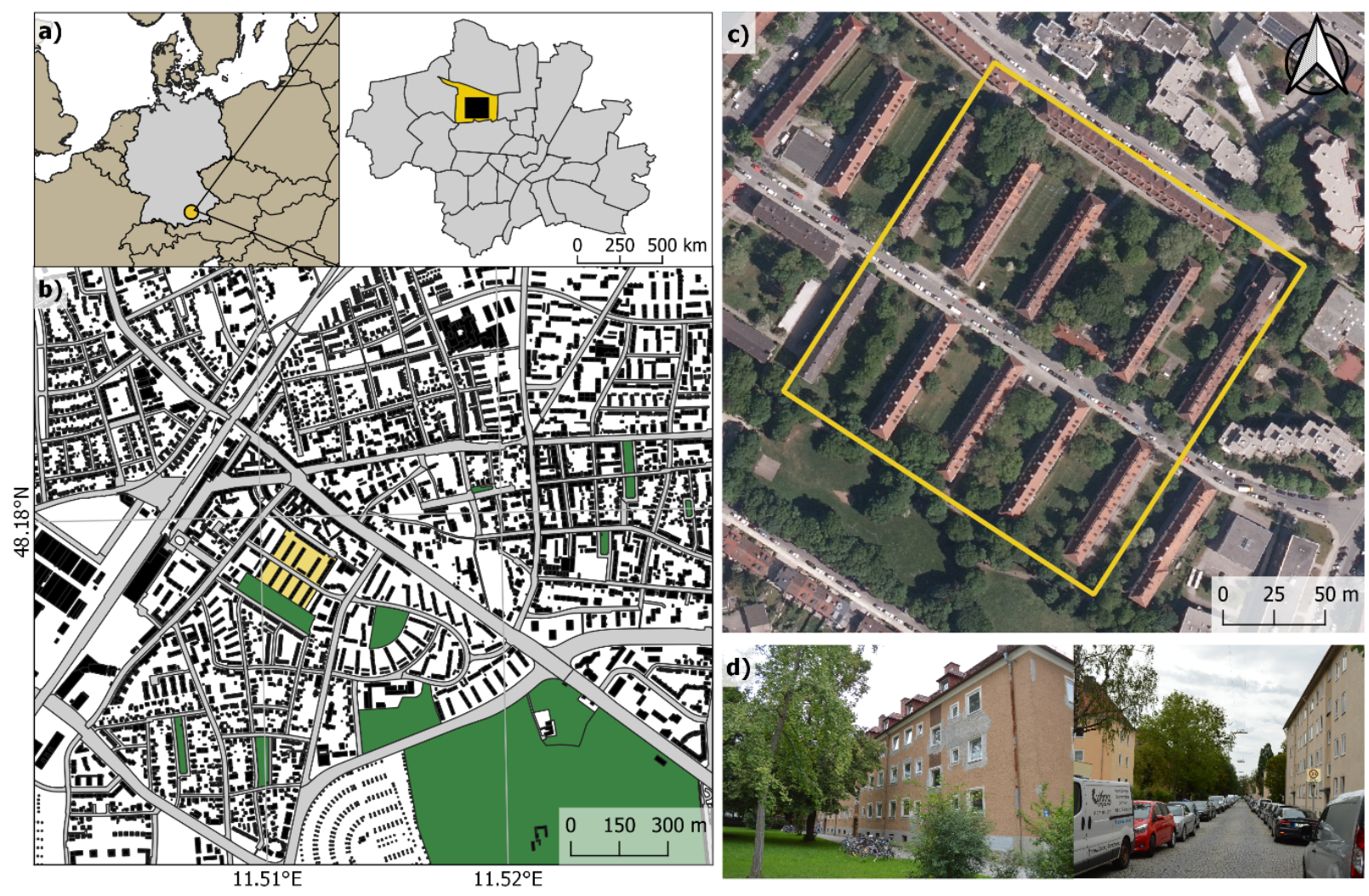

Figure 1. Spatial assignment of investigation area. Location of the city district Moosach within Munich (a); map of the study site's wider neighbourhood (b); aerial image of the study site (c); row buildings and the middle street in the study site (d). Source: Sabrina Erlwein (with basic geographical data provided by the Bavarian State Office for Survey and Geoinformation 2018). 
Although most of the areas were well connected to transport nodes and thus qualified for a parking space reduction, the ratio of parking spaces per residential unit was reduced from 1 to 0.6 only in three out of 35 local plans. Moreover, in $91.5 \%$ of the plans analysed, the required parking spaces had to be provided by underground car parks. The areas designated for underground parking usually extended over the entire green space between the buildings. Therefore, parking space provision was identified as one key parameter affecting green space provision.

Additionally, four workshops were held with city planners involved in the redevelopment of the study area (24 June, 25 July, 10 October, 16 December 2019). The participants included personnel from the Department of Urban Planning and Building Regulations (overall project management and green planning) and the Department of Health and Environment (climate change mitigation and adaptation). While the first two meetings focussed on planning challenges and goals for the development area and identification of key parameters for densifica- tion, the last two were used to discuss and refine the developed densification scenarios.

The scenarios are distinct by i) type of densification, ii) building height and iii) number of underground car parks (Figure 2). The category 'type of densification' distinguishes between the addition of floors, in which the buildings' free-standing form is retained $(\mathrm{O}=$ open blocks), and the addition of buildings, whereby the existing buildings are closed alongside the road ( $C=$ closed rows). The building height varies between one and two additional floors (in total 15/18 m). Furthermore, we varied the number of underground car parks $(a=1, b=4$, $c=8$ ) to reflect the different parking space policies. For instance, the additional housing units gained by adding one floor (Table 1) could be supplied by the existing underground car park (a), if the parking space key was reduced to 0.3 . If the current regulation was applied or if the ratio was even increased, four (b) or more (c) underground car parks would be necessary. The construction of underground car parks causes the removal of existing trees from the designated areas. In case b (four

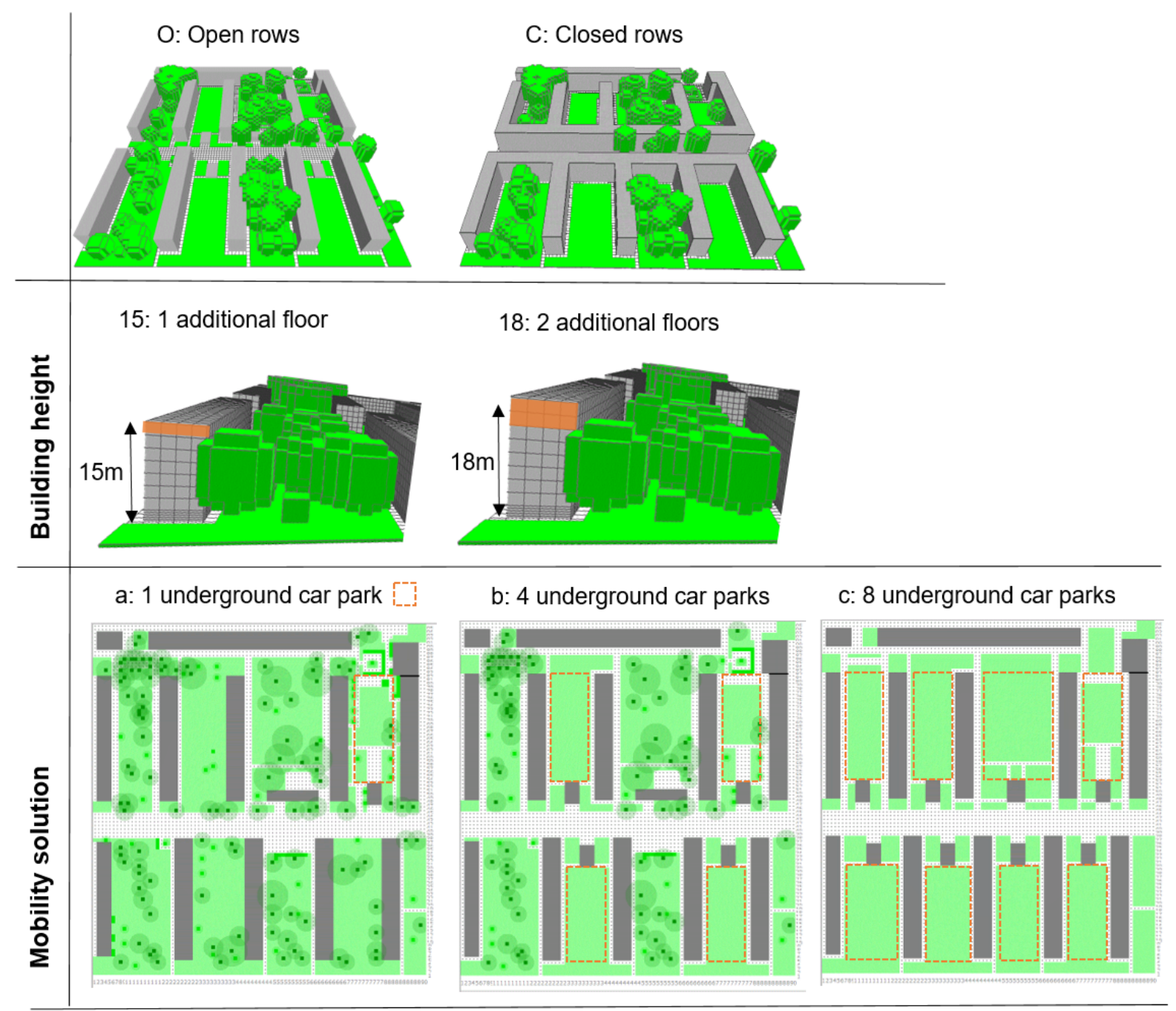

Figure 2. Scheme for all densification scenarios with basic categories of densification type, building height and mobility solution; locations of underground car parks are marked with dashed lines. Source: Sabrina Erlwein. 
Table 1. Overview of the basic parameters of the densification scenarios.

\begin{tabular}{lcccccc}
\hline Scenario & $\begin{array}{c}\text { Built } \\
\text { surface }\end{array}$ & $\begin{array}{c}\text { Floor area } \\
\text { ratio }\end{array}$ & $\begin{array}{c}\text { Building } \\
\text { height }\end{array}$ & $\begin{array}{c}\text { Number } \\
\text { of trees }\end{array}$ & $\begin{array}{c}\text { Number } \\
\text { of flats* }\end{array}$ & $\begin{array}{c}\text { Underground } \\
\text { parking }\end{array}$ \\
\hline Status Quo & $24.1 \%$ & 0.8 & $13 \mathrm{~m} * *$ & 158 & 376 & 1 \\
O15a & $24.1 \%$ & 1.3 & $15 \mathrm{~m}$ & 158 & 427 & 1 \\
O15b & $24.1 \%$ & 1.3 & $15 \mathrm{~m}$ & 102 & 427 & 4 \\
O15c & $24.1 \%$ & 1.3 & $15 \mathrm{~m}$ & 0 & 427 & 8 \\
C15b & $31.1 \%$ & 1.7 & $15 \mathrm{~m}$ & 84 & 552 & 4 \\
C15c & $31.1 \%$ & 1.7 & $15 \mathrm{~m}$ & 0 & 552 & 4 \\
O18b & $24.1 \%$ & 1.6 & $18 \mathrm{~m}$ & 102 & 512 & 8 \\
O18c & $24.1 \%$ & 1.6 & $18 \mathrm{~m}$ & 0 & 512 & 8 \\
C18c & $31.1 \%$ & 2.5 & $18 \mathrm{~m}$ & 0 & 663 & 8 \\
\hline
\end{tabular}

Notes: * = Calculation of flats: Current status $46,5 \mathrm{~m}^{2}$ per flat, after redevelopment $67,5 \mathrm{~m}^{2}$ per flat; ${ }^{* *}=$ Saddle roof

underground car parks), the underground car parks were preferably assigned to lawns with a few trees to preserve as many trees as possible.

Further modification of supply of greenery included the removal of all the trees that were closer than $4 \mathrm{~m}$ to the buildings since they would not survive the construction works. The name of the scenario indicates the parameters used (e.g., O15b = open rows, $15 \mathrm{~m}$ height and four underground car parks). Since the chosen scenarios reflect planning scenarios, not all twelve conceivable combinations were simulated but only those that could occur in reality. For instance, in the case of the most extreme densification (C18), parking demand triggered by new flats would be too high to be covered by just four underground car parks, thus only scenario C18c was simulated. To calculate the number of new apartments for each scenario, we used actual data from the housing association. After the renovation, the living space per residential unit would increase from the current 46.5 to $67.5 \mathrm{~m}^{2}$.

\subsection{Urban Micrometeorological Simulation Model ENVI-Met}

All simulations in this study were performed with the three dimensional microscale model ENVI-met (Bruse \& Fleer, 1998; Simon, 2016), version 4.4.3. ENVI-met is one of the most widely used simulation tools, being successfully applied in various contexts and geographical zones for micrometeorological investigations (Tsoka, Tsikaloudaki, \& Theodosiou, 2018). ENVI-met considers complex interactions of building structures, atmosphere, soil and vegetation processes (Simon et al., 2018), with a typical resolution of $0.5-10 \mathrm{~m}$ in space and up to $2 \mathrm{~s}$ in time. Numerous studies have assessed the model's accuracy and have testified it to be well suited to outdoor comfort investigations, especially during daytime (Acero \& Arrizabalaga, 2018; Lee, Mayer, \& Chen, 2016). The ENVI-met application BIOMET allows the calculation of several thermal comfort indices, such as Universal Thermal Comfort Index and PET. The PET was chosen for this study as it is adapted for outdoor settings (Mayer \&
Höppe, 1987), constitutes one of the recommended thermal comfort indices for human bio-meteorological investigations (Staiger, Laschewski, \& Matzarakis, 2019), and is frequently used and thus further developed (Hirashima et al., 2018). In a recent calibration for the German cities Kassel and Freiburg, PET values above $35^{\circ} \mathrm{C}$ were perceived as hot and PET values above $38^{\circ} \mathrm{C}$ as very hot (Hirashima et al., 2018), while Holst and Mayer (2010) suggest a PET transition value of $35^{\circ} \mathrm{C}$ toward warm and $40^{\circ} \mathrm{C}$ toward hot based on investigations in Freiburg. Recently, Zölch, Rahman, Pfleiderer, Wagner, and Pauleit (2019) evaluated the model performance of ENVI-met for Munich and found an underestimation of $T_{a}$ during the evening hours of 1.0-1.5 K. However, the overall model performance was found to be satisfactory ( $R^{2}$ of 0.94$)$. Therefore ENVI-met is regarded as a suitable micrometeorological investigation tool for this study.

\subsection{Model Configuration and Meteorological Input Data}

The required meteorological data for the ENVI-met simulation were extracted from the weather station of the German Meteorological Service, City-Station ID 3379, located approximately $2.8 \mathrm{~km}$ from the study area. The weather data for the past 10 years were analysed to select two running days (4 and 5 of July 2015) that representes typical hot days. Hot days are characterised by daytime maximum $\mathrm{T}_{a}$ above $30^{\circ} \mathrm{C}$ and a nightly $T_{a}$ not below $20^{\circ} \mathrm{C}$, with clear skies and low wind speed (up to $2 \mathrm{~m} / \mathrm{s}$; Mühlbacher et al., 2020). This focus was chosen as the number and intensity of hot days is likely to increase due to climate change (Mühlbacher et al., 2020). Heat stress negatively affects human health leading to a lack of concentration, exhaustion, dehydration, heat stroke, hyperthermia and eventually death (Ward Thompson, Lauf, Kleinschmit, \& Endlicher, 2016). ENVI-met version 4.4.3 allows full forcing of wind speed and wind direction. However, if the wind direction changes too fast, the simulation is aborted. Thus, the most common wind direction for each hour during summertime was statistically identified based on the German Meteorological Service weather station data (1985-2018) and used as model input. 
A figure presenting all the meteorological input variables can be found in S1 of the Supplementary File.

The chosen horizontal and vertical resolution of $2 \times 2$ m represents a compromise between sufficient geometric detail and sufficient computational speed (Zölch et al., 2016). For higher accuracy of surface interactions, the lowest vertical cell was further divided into five subboxes. The grid was rotated $32^{\circ}$ from the north to rectify the building structure. The building heights and dimensions were derived from the GIS-Data provided by the City of Munich. The pavement and building materials were identified by visits to the site (for configuration details see Table 2 ).

Recent tree inspection data (including tree species, tree height and crown dimensions) from the municipal company were available for most of the study area. The data were supplemented by on-the-spot visits to include missing trees and to identify unclear tree locations. Out of 158 trees, 27 different tree species were identified in the study area and were sorted into five different categories for the sake of simplification. As the main cooling effect of trees is attributed to shading (Erell et al., 2011), the focus was set on tree characteristics that influence the reduction of radiation load, namely tree height, canopy shape and foliage density (Rahman, Stratopoulos et al., 2020). Based on the inspection data and on definitions of the City of Munich from local plans, we defined three different tree heights (small $=6 \mathrm{~m}$, medium $=15 \mathrm{~m}$, large $=22 \mathrm{~m}$ ), into which the existing trees were classified. The crown height to diameter ratio was calculated for each tree to sort it into either spherical or cylindrical crown form. However, all the small trees were grouped into one category since differences among their crown shapes were small. ENVI-met uses the leaf area density (LAD) to define the foliage density. The LAD values of predefined species in ENVI-met's tree manager Albero range from 0.4 (populus alba) to 2.0 (e.g., acer platanoides). For new tree configurations, Albero offers LAD $0.3 \mathrm{~m}^{2} / \mathrm{m}^{3}$ and LAD $1.1 \mathrm{~m}^{2} / \mathrm{m}^{3}$ as standard values. Since foliage density also varies within species due to the growing season and the tree's age (Rahman, Stratopoulos et al., 2020), which complicates representation by categories and tree parametrisation not being the aim of this study, the medium LAD of $1.1 \mathrm{~m}^{2} / \mathrm{m}^{3}$ was chosen for all tree categories. The final five tree categories including their parameters are presented in Table 3.

Simulations were launched at 6 am for a total model time of 48 hours (Table 2). We excluded the first 24 hours from the analysis to overcome initial transient conditions. Simulation outcomes were analysed for the hottest ( $2 \mathrm{pm}$ ) and coolest hour ( $4 \mathrm{am})$, to detect possible trade-offs between daytime and night-time at a pedestrian level of $1.4 \mathrm{~m}$ height (approximating to the humanbiometeorological reference height; Mayer \& Höppe, 1987). In addition, we computed and mapped the averages from 10 am to $4 \mathrm{pm}$ to better depict the design parameters' influence on the shadow cast during the day (Holst \& Mayer, 2011). Compared to an analysis of just one point in time, this makes it possible to derive more robust design implications (Lee et al., 2016).

Table 2. ENVI-met model setup and meteorological input data.

\begin{tabular}{ll}
\hline Start of simulation & 4 July $2015,6 \mathrm{am}$ \\
Duration of simulations & $48 \mathrm{~h}$ \\
Modell grid size/resolution & $90 \times 95 \times 25 / 2 \times 2 \mathrm{~m}$ \\
Building materials & Brick (wall), tile (roof) \\
Wind speed (10 m above ground) & $0.7 \mathrm{~m}-\mathrm{s}-2.0 \mathrm{~m} / \mathrm{s}$ \\
Wind direction & $240^{\circ}-310^{\circ}$ \\
Max/min $\mathrm{T}_{\mathrm{a}}$ & $35.4^{\circ} \mathrm{C} / 21.7^{\circ} \mathrm{C}$ \\
Cloud cover & cloud-free \\
Lateral boundary conditions & Full forcing \\
Initial soil temperature & Upper layer $(0-0.2 \mathrm{~m}): 23.85^{\circ} \mathrm{C}$, middle layer $(-0.5 \mathrm{~m}): 23.9^{\circ} \mathrm{C}$, \\
& deep layer $(-2 \mathrm{~m}): 19.9^{\circ} \mathrm{C}$ \\
Relative soil humidity & Upper layer: $50 \% ;$ middle and deep layer: $60 \%$ \\
\hline
\end{tabular}

Table 3. Tree categories used in the ENVI-met simulation (base case).

\begin{tabular}{clccrr}
\hline Category & Size & Height & Diameter & LAD & Count \\
\hline K1 & Small (all forms) & $6 \mathrm{~m}$ & $5 \mathrm{~m}$ & 1.1 & 44 \\
K2 & Medium, spherical & $15 \mathrm{~m}$ & $11 \mathrm{~m}$ & 1.1 & 19 \\
K3 & Medium, cylindrical & $15 \mathrm{~m}$ & $9 \mathrm{~m}$ & 1.1 & 50 \\
K4 & Large, spherical & $22 \mathrm{~m}$ & $17 \mathrm{~m}$ & 1.1 & 12 \\
K5 & Large, cylindrical & $22 \mathrm{~m}$ & $11 \mathrm{~m}$ & 1.1 & 34 \\
\hline
\end{tabular}




\section{Results}

\subsection{Comparison of Day-Time Thermal Comfort for the Current Situation and Densification Scenarios}

Simulation results for the current situation reveal overall very hot thermal conditions for pedestrians at $2 \mathrm{pm}$ (Figure 3). Nearly $100 \%$ of the study area experiences extreme heat stress (PET mean value of $46.9^{\circ} \mathrm{C}$ ). The coolest locations were found in the shadows of trees and buildings (PET $\left.41^{\circ} \mathrm{C}-43^{\circ} \mathrm{C}\right)$, whereas the thermal hotspots were found in front of the sun-facing façades (SE orientation) and the poorly ventilated areas (PET $\left.55^{\circ} \mathrm{C}-56.6^{\circ} \mathrm{C}\right)$. This pattern was mainly attributed to the impact of solar radiation as expressed by the mean radiant temperature. On cloudless summer days, the mean radiant temperature is the dominating factor for outdoor human thermal comfort in Central Europe (Ali-Toudert \& Mayer, 2007; Holst \& Mayer, 2011; Lee \& Mayer, 2018). All densification scenarios except for scenario 015a, were, on average, hotter than the base case. In scenario $015 \mathrm{a}$, the buildings were raised by one storey, but the existing vegetation was completely preserved. There, the full tree canopy combined with the additional shadow cast from the elevated buildings further reduced the short-wave radiation densities and thus improved the thermal comfort compared to the base case. The impact of additional underground car parks becomes visible in the remaining scenarios: The higher the number of removed trees, the greater the penetration of solar radiation and the higher the median PET (Figure 4a). Remarkably, at noon the median difference between $100 \%$ trees and $65 \%-53 \%$ trees is larger than that between the latter and zero trees (PET median difference of $2.0^{\circ} \mathrm{C}-2.1^{\circ} \mathrm{C}$ compared to $0.5^{\circ} \mathrm{C}-0.6^{\circ} \mathrm{C}$ ). However, while in scenarios with $65 \%-53 \%$ trees, $75 \%$ of all locations were cooler than $50^{\circ} \mathrm{C}$ (PET), nearly half of the study area in the tree-less scenarios was hotter than $50^{\circ} \mathrm{C}$ (PET; Figure 3, Figure 4). The variety of cooler and hotter grid cells is higher in scenarios with trees (PET interquartile range of $5.9^{\circ} \mathrm{C}-5.4^{\circ} \mathrm{C}$ to $3.2^{\circ} \mathrm{C}-1.3^{\circ} \mathrm{C}$ ) but also in scenarios with a more closed building arrangement compared to the default arrangement of free-standing blocks. Building heights have only a marginal impact on noon simulation outcomes.

The closure of the building rows has two opposing effects: On the one hand, the newly introduced buildings shade one side of the street and a portion of the northern

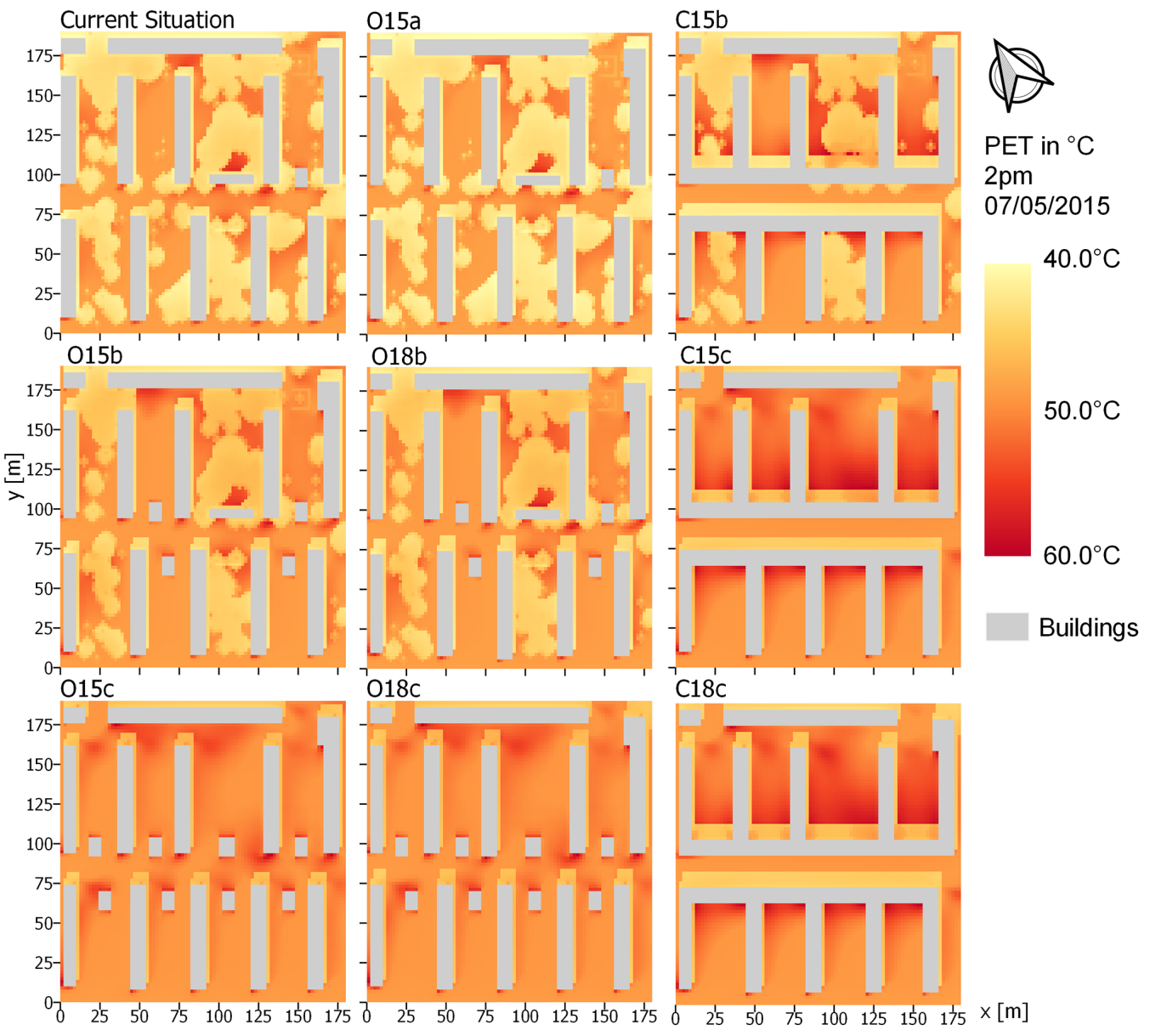

Figure 3. Simulated PET values at 2 pm on 5 July 2015 for the current situation and the eight densification scenarios (1.4 $\mathrm{m}$ height). Notes: $\mathrm{O}=$ open rows, $\mathrm{C}=$ closed rows; $15 / 18=15 / 18 \mathrm{~m}$ building height; $\mathrm{a} / \mathrm{b} / \mathrm{c}=1 / 4 / 8$ underground car parks. Source: Sabrina Erlwein. 

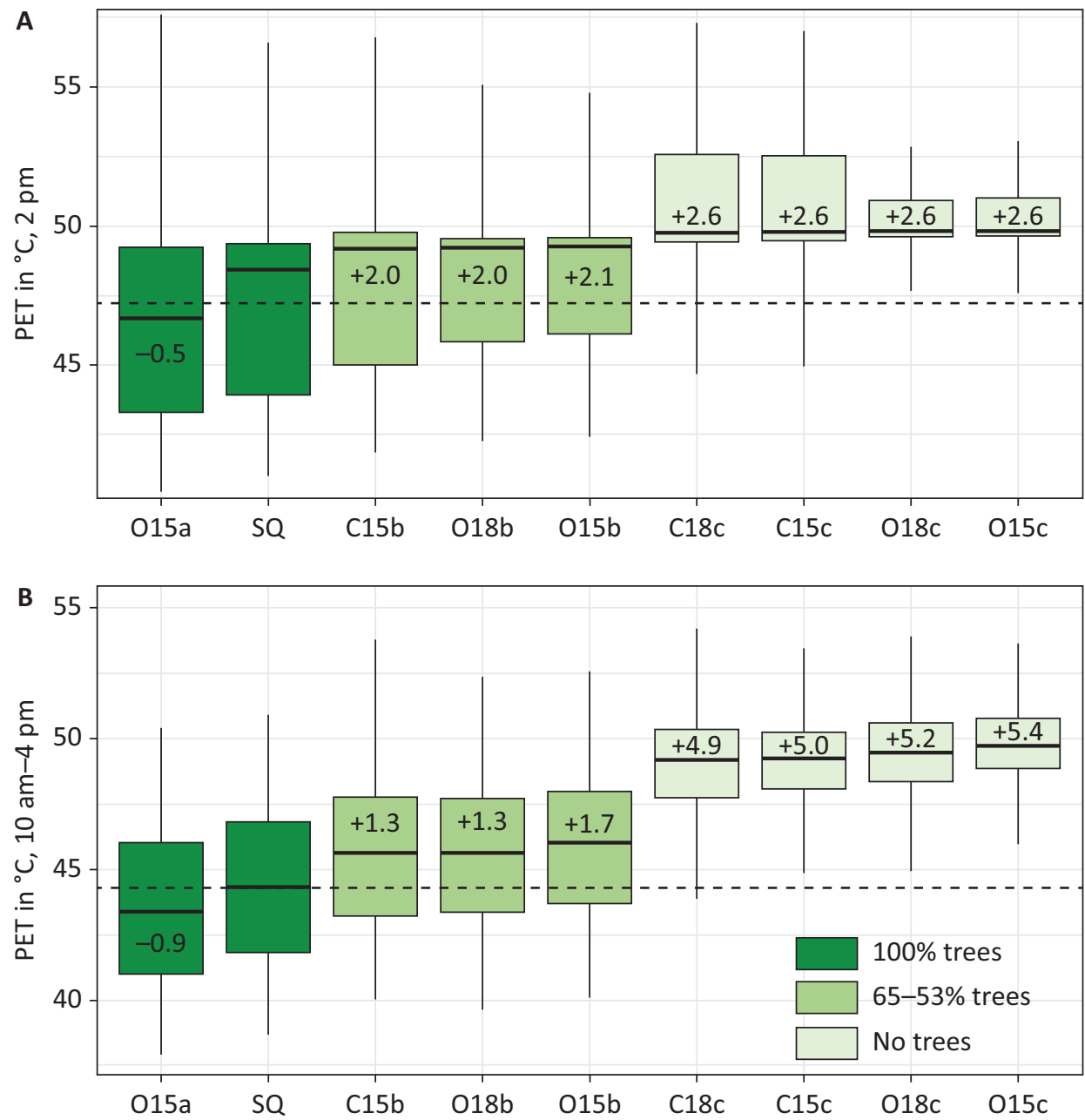

Figure 4. Boxplots of the PET values for all densification scenarios at $2 \mathrm{pm}$ (A) and $10 \mathrm{am}-4 \mathrm{pm}$ (B) on 5 July 2015. The colours refer to the number of trees in the respective scenario. The dashed line marks the median value of the current situation; the numbers in the boxes indicate the respective deviation from the base case (=SQ) median. Source: Sabrina Erlwein.

yards. On the other hand, heat accumulates especially in the northern yards, enlarging the total area with PET values above $51^{\circ} \mathrm{C}$ to nearly $40 \%$ (compared to $7 \%$ in the current situation and $23 \%-25 \%$ in the open row simulations; see S2 of the Supplementary File). At the same time, wind speed in the enclosed yards is $-0.6 \mathrm{~m} \mathrm{~s}-1$ lower compared to the open row configuration, whereas elevated wind speed in the middle street indicates a channelling effect (Figure 5).

If not only the hottest hour, but the time period from 10 am to $4 \mathrm{pm}$ is considered, the contrast between $100 \%$ (category $\mathrm{c}$ ) and $50 \%$ (category $\mathrm{b}$ ) tree removal becomes more prominent (Figure 4, A). The removal of all existing trees leads to an increase in average PET by $4.9^{\circ} \mathrm{C}-5.4^{\circ} \mathrm{C}$ compared to the current situation. This increase can be considered as a significant deterioration of thermal comfort under a human-biometeorological perspective. In contrast, average increase in PET is reduced to $1.3^{\circ} \mathrm{C}-1.7^{\circ} \mathrm{C}$ if only half of the trees are removed. While the largest differences in thermal comfort are again attributed to the presence of trees and their blocking of direct solar radiation, higher building heights result in slightly lower PET temperature averages $\left(0.1^{\circ} \mathrm{C}-0.4^{\circ} \mathrm{C}\right)$, both for the open row and closed row configuration. This is because higher buildings cast more shadows and thus reduce the mean radiant temperature. The hottest overall thermal conditions are observed for scenario 015c, without trees, open rows and lower building heights, while scenario 015a (all trees preserved) is the coolest one. For the spatial distribution of PET values, see S4 of the Supplementary File.

\subsection{Comparison of Night-Time (4 am) Thermal Comfort for the Current Situation and Densification Scenarios}

In contrast to the daytime situation, in the early morning $(4 \mathrm{am})$ green spaces with high tree cover are slightly warmer $\left(+0.9^{\circ} \mathrm{C}\right.$ for PET) than only grassed areas. Tree canopies reduce the amount of out-going longwave radiation and retain daily heat, while high sky view factors are beneficial for nocturnal cooling. The warmest spots are located in the vicinity of NE oriented building facades, whereas non-disclosed areas are the coolest ones (Figure 6). The PET averages $18.8^{\circ} \mathrm{C}$ for the base 

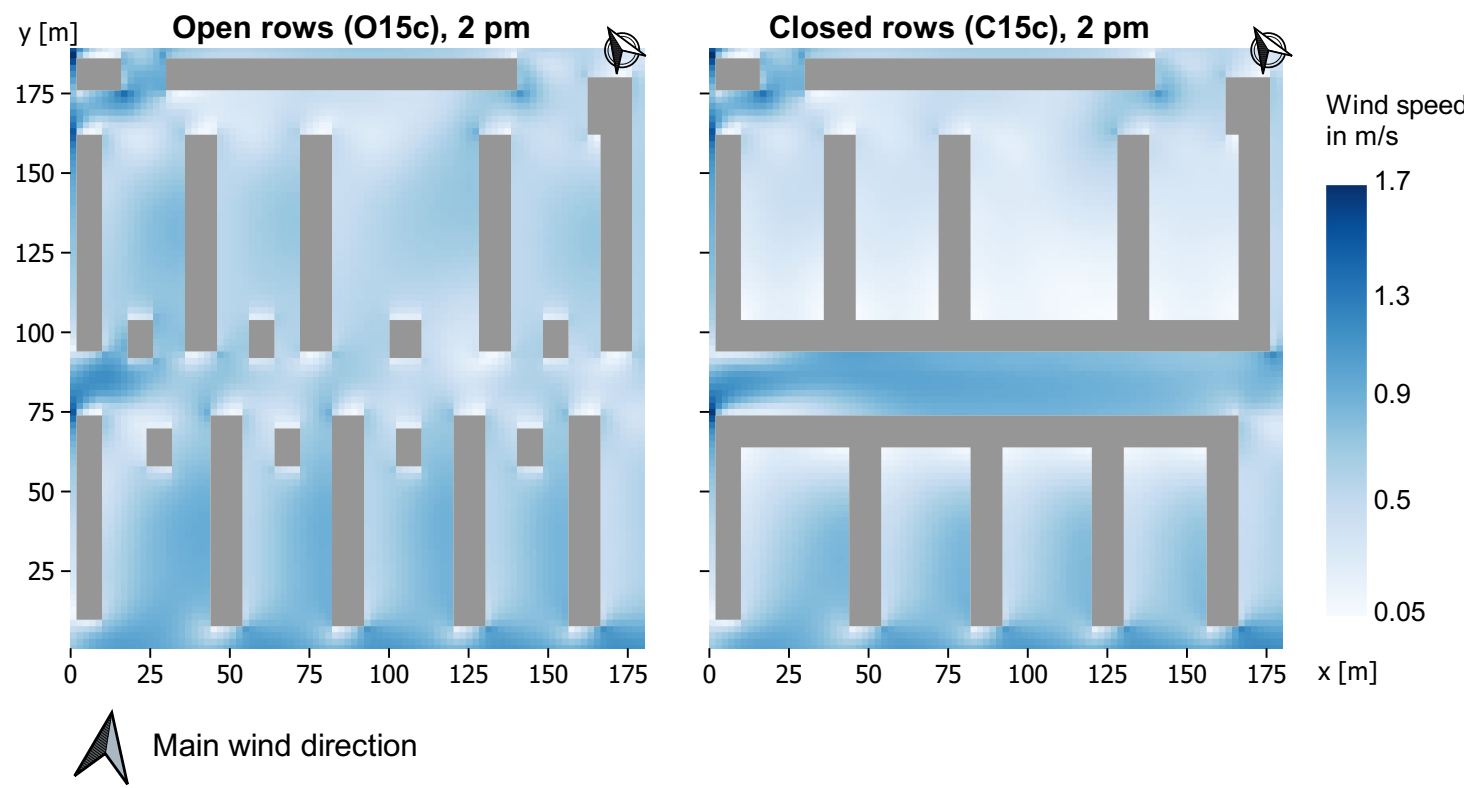

Figure 5. Wind speed at $1.4 \mathrm{~m}$ height for two different building configurations without trees on 5 July 2015. Source: Sabrina Erlwein.

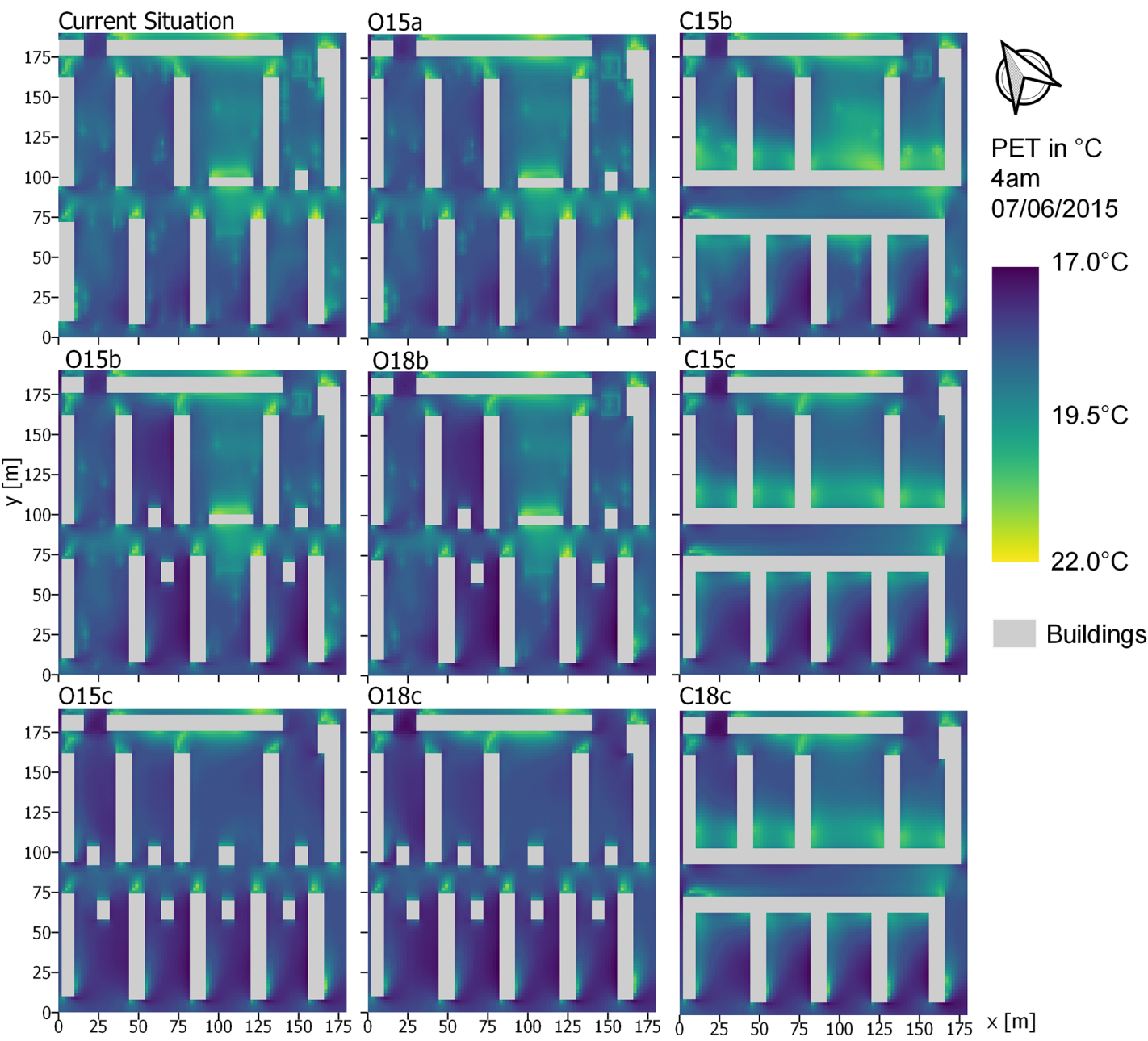

Figure 6. Simulated PET values at 4 am for the current situation and the eight densification scenarios (1.4 $\mathrm{m}$ height). Notes: $\mathrm{O}=$ open rows; $\mathrm{C}=$ closed rows, $15 / 18=15 / 18 \mathrm{~m}$ building height, $\mathrm{a} / \mathrm{b} / \mathrm{c}=1 / 4 / 8$ underground car parks. Source: Sabrina Erlwein. 
case (Figure 7). In the absence of solar radiation, the PET range between the warmest and the coolest spot is just $4.1^{\circ} \mathrm{C} \mathrm{PET}$ (and $0.8^{\circ} \mathrm{C}$ for $\mathrm{T}_{\mathrm{a}}$ ). Only scenario $\mathrm{C} 15 \mathrm{~b}$ (closed rows, trees in every 2 nd courtyard) is on average warmer $\left(+0.1^{\circ} \mathrm{C}\right.$ for PET) than the current situation (Figure 7). However, differences in average PET are small $\left(18.4^{\circ} \mathrm{C}\right.$ to $18.9^{\circ} \mathrm{C}$ ). Unlike during the day, the number of trees and the sky view factor in the respective set-up are not the most influential factors for thermal comfort. Instead, building arrangements with open rows that permit infiltration of airflow are cooler than the 'closed rows' design scenarios. Similar to the daytime observations, the northern courtyards are more affected by an elevated temperature than the southern ones $\left(18.7^{\circ} \mathrm{C}\right.$ vs $20.0^{\circ} \mathrm{C}$ for $\mathrm{PET})$. In the warmest scenario, combining closed rows with longwave radiation retaining tree canopies (C15b), $45 \%$ of the area is warmer than $19^{\circ} \mathrm{C}$, while it is $12 \%$ for the coolest scenario $018 \mathrm{c}$ (open rows, no trees; S3 of the Supplementary File). Higher buildings heights are associated with a lower overall PET.

For side-by-side comparison of all the modelling results for daytime and night-time, Figure 8 depicts the average PET deviations of all the densification scenario outcomes from the current situation.

\section{Discussion}

When comparing eight densification scenarios for an urban redevelopment site, preservation of the existing vegetation was identified as the most important parameter in reducing diurnal outdoor heat stress. All treeless scenarios were significantly hotter regardless of densification type and building height, followed by those scenarios featuring a reduced amount of vegetation. These findings are in line with other studies that identified trees as being the most efficient in heat mitigation due to their shading potential (Chatzidimitriou \& Yannas, 2016; Erell, 2017; Lee et al., 2016;). Open spaces with high sky view factors cool down faster during the night-time as heat dissipation is not hindered by obstacles (Erell et al., 2011). Tree canopies trap radiant heat at night, retaining daytime heat (Bowler et al., 2010). Thus, most of the densification scenarios are hotter during daytime and cooler during night-time, due to their reduced number of trees; however, free flows of cooling wind are equally important. The four coolest scenarios at 4 am were those with open row buildings as south-westerly airflow can penetrate into the green spaces between the buildings. With closed rows, these wind flows are blocked (reducing wind speed by $0.6 \mathrm{~m} / \mathrm{s}$ ), this being especially detrimental for the northern courtyards. There, night-time PET ( $4 \mathrm{am})$ is up to $2.0^{\circ} \mathrm{C}$ warmer and daytime PET ( $\left.2 \mathrm{pm}\right)$ is as much as $4.8^{\circ} \mathrm{C}-6.8^{\circ} \mathrm{C}$ warmer.

While a large number of studies have shown how adding green infrastructure can help to mitigate increased summer temperature (Lee et al., 2016; Perini \& Magliocco, 2014; Zölch et al., 2016), this study stresses that preservation of fully grown and high quality green infrastructure elements in urban redevelopment sites is equally important. The cooling capacity of trees is not uniform, but depends on tree species, growing conditions (Rahman, Moser, Rötzer, \& Pauleit, 2019), geographical location, season (Jamei et al., 2016), placement of trees and individual tree parameters (e.g., tree height, healthiness; Rahman, Stratopoulos et al., 2020). In fact, several authors argue that a lower number of urban green spaces in growing cities might be substituted by improving their quality (Artmann, Inostroza, \& Fan, 2019; Haaland, \& van den Bosch, 2015). Similarly, a loss of urban green space might be acceptable if the

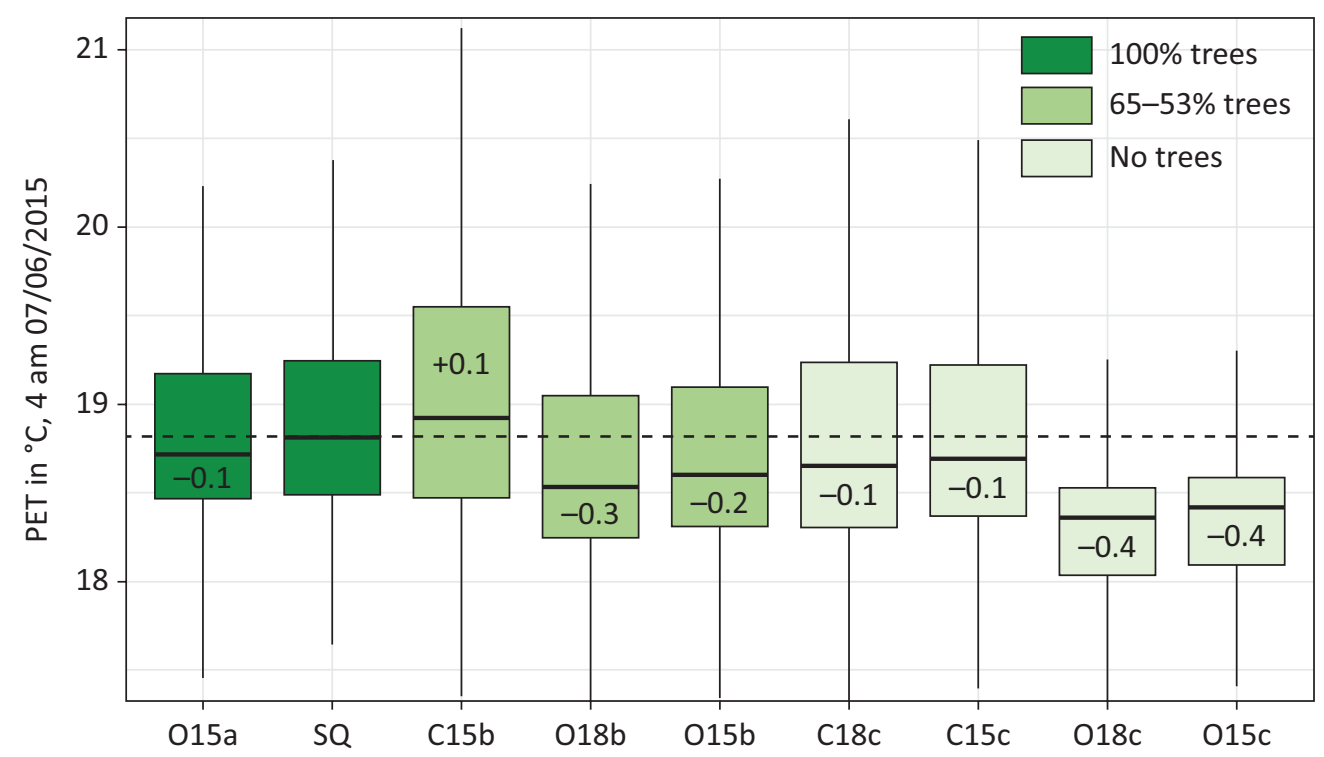

Figure 7. Boxplots of PET values for all the densification scenarios at 4 am on 5 July 2015. Notes: The colours refer to the number of trees in the respective scenario. The dashed line marks the median value of the current situation; the numbers in the boxes indicate the respective deviation from the base case (=SQ) median. Source: Sabrina Erlwein. 


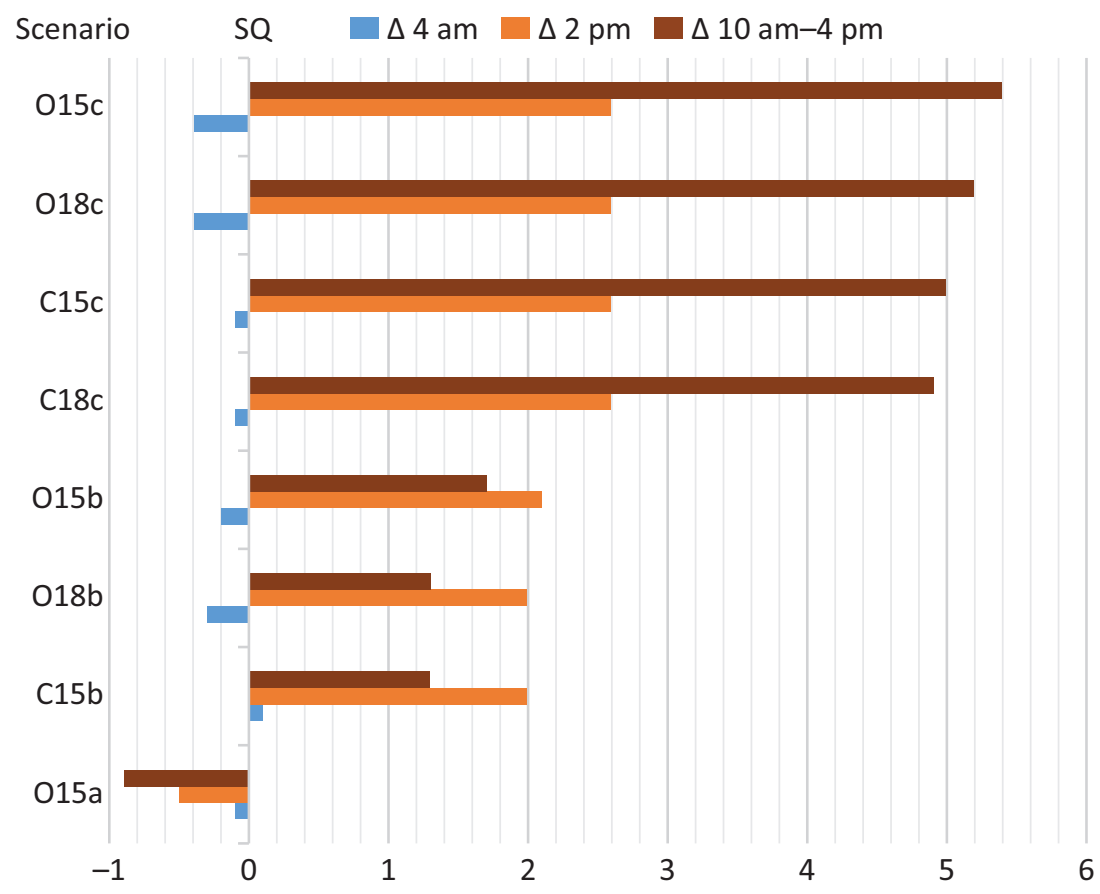

Figure 8. Deviations (in ${ }^{\circ} \mathrm{C}$ ) from the average PET of the current situation for daytime (5 July 2015) and 4 am (6 July 2015) for all the densification scenarios. Notes: $\mathrm{O}=$ open rows; $\mathrm{C}=$ closed rows, $15 / 18=15 / 18 \mathrm{~m}$ building height, $\mathrm{a} / \mathrm{b} / \mathrm{c}=1 / 4 / 8$ underground car parks. Source: Sabrina Erlwein.

existing qualities are preserved. However, newly planted trees are unlikely to be fully grown trees, but rather small trees with limited crown volumes. Growing conditions for urban trees are often harsh due to limited growth volumes, compacted soils and reduced water availability (Moser, Rötzer, Pauleit, \& Pretzsch, 2015). As the replanting of trees is time-consuming and often associated with high costs, the loss of old shade-giving trees cannot be easily compensated in the short or medium term. Where construction of underground car parks was limited to $50 \%$ and yards with fewer or smaller trees were selected for that purpose (' $b$ '-scenarios) the PET increases through densification could be limited to $+1.3^{\circ} \mathrm{C}$ for the daytime average (10 am to $4 \mathrm{pm}$ ).

\subsection{Limitations of the Methodological Approach}

The presented study focused on an extreme weather condition of severe summer heat and low wind speed to compare different densification impacts. This focus is due to the fact that climate change is likely to exacerbate already elevated urban heat. As a result, PET values for the chosen heat stress situation were very high; even in the shade of trees, thermal comfort levels remained on an extreme heat stress level. Since a heatwave with no rain preceded the modelling day, the soil humidity was decreased from $75 \%$ to $50 \%$ according to the available measurement data. Bande et al. (2019) found an overestimation of the mean radiant temperature values in ENVI-met due to the soil properties and report limits in the vertical moisture transfer with the top layer drying out too quickly. Thus, the exceptionally high PET values might have been caused by the limited availability of soil moisture. Nevertheless, the findings of this study are still considered valid, as the main focus of the study was set on comparing the relative differences between the investigated densification scenarios rather than on reporting the absolute PET values. All the simulation runs were performed under the same meteorological and identical full forcing conditions in the ENVI-met model.

The model outcomes are representative for similar building geometries, that are widespread in German cities. However, the impacts of building geometry alterations on the mean radiant temperature and subsequently PET are dependent on axis orientation and main wind directions (Chatzidimitriou \& Axarli, 2017; Holst \& Mayer, 2011). Due to the row building's NE-SW orientation, only a small part of the area benefitted from the enlarged shadow cast due to the increased building height during the hottest hours of the day. With an E-W orientation, additional shade due to higher building height might have made a more important contribution. For improved transferability of results, more axis orientations and main wind directions would need to be studied.

In light of climate change, we investigated thermal comfort situations for daytime and night-time for a hot summer situation. However, if planners seek to optimise thermal comfort throughout the year, potential trade-offs between different seasons should be considered. For instance, although detrimental in the summertime, wind-blocking by trees in winter might be beneficial especially in colder climates to reduce wind chill effects (Sjöman, Hirons, \& Sjöman, 2016). However, from a climate change perspective, the situation of heat 
waves during hot summertime is of particular concern for climate-sensitive urban planning in Central European cities such as Munich.

\subsection{Implications for Urban Planners}

This study showed that trees play a pivotal role in heat stress mitigation and that preservation of existing trees is the most efficient and most affordable measure for climate change adaptation. In practice, the provision of new apartments leads to an increased need for parking spaces, resulting in tree removals. To balance housing demand and preservation of urban green space, the following recommendations can be given to urban planners.

First, particularly in the case of inner-city locations that are usually well connected to public transport, parking space ratios should be reduced by the employment of mobility concepts. Car-sharing and bike-sharing stations guarantee individual mobility, whereby strengthening of public transport is not only beneficial for the residents, but also for the entire neighbourhood (Stevenson et al., 2016).

Second, we recommend that architects and planners seek an early consideration of valuable mature vegetation in the built layout. If the construction of underground car parking is necessary, this should preferably be located in those areas with fewer trees. This is also important considering the fact that trees not only improve the local microclimate but also provide multiple ecosystem services such as stormwater retention, biodiversity and increased well-being (Hansen \& Pauleit, 2014). In comparison to preservation, the replacement of trees is a time- and cost-consuming process.

Third, for the investigated free-standing multistorey housing type, densification through additional storeys is more beneficial in terms of climate adaptation than the addition of buildings. Although the addition of new buildings creates two to three times more new flats, this comes at the cost of lost unsealed open space and additional tree removals. The heat burden in closed building arrangements is significantly increased for areas with low wind speed, both for daytime and night-time. While shading by trees is an option to reduce daytime human heat stress (Lee et al., 2020; Rahman, Hartmann et al., 2020), tree canopies will exacerbate the nocturnal situation in those yards. Designs that consider nocturnal airflow will improve thermal comfort.

Finally, we recommend perceiving densification not only as a threat but also as a chance for upgrading urban green spaces and for introducing new green elements. To do so, we suggest the strategic planting of trees in thermal hotspots and taking care that good growing conditions are provided (see also Zölch et al., 2019). Green infrastructure elements can be combined with blue infrastructure elements such as rain gardens, to improve stormwater retention and water supply for the existing vegetation under dry conditions. Thus, meeting the increased housing demand can be achieved while green quality is increased.

\section{Conclusions}

This study investigated the impact of densification on urban green space availability and outdoor thermal comfort for an open midrise development site in Munich. Densification scenarios for a typical housing area of freestanding multistorey blocks in Munich were developed alongside planners and were thus considered to be realistic. We showed that the construction of parking space and the loss of existing trees have the greatest impact on PET outcomes. Replacing large trees is not only costly and time-consuming but is also ineffective in the short to medium term. Maintaining existing and mature vegetation reduces PET increase by $4^{\circ} \mathrm{C}$ compared to the base case (10 am to $4 \mathrm{pm})$. Thereby, the cooling effect during daytime outweighs the slight warming due to heat trapping at night. Wind blocking by buildings and trees reduces thermal comfort even in low wind conditions $(<2 \mathrm{~m} / \mathrm{s})$. Thus, additional buildings should be carefully placed. Discussions with planners revealed that such quantitative information is urgently needed to consider the impacts of densification on human thermal comfort. Thus, this study contributed some important insights into urban planning. In light of climate change, mobility strategies that reduce the need for both aboveground and below-ground parking space are required for climate-sensitive densification of built areas. Future research should investigate thermal comfort during different seasons that have different requirements for light availability and shading. Other settlement types, benefits to stormwater management and the impacts or potentials of changed surfaces and materials, e.g., wood instead of concrete construction, require further investigation. Further studies should also analyse the perception of the quality of outdoor open spaces with regard to thermal comfort, but also the relationship between indoor and outdoor thermal comfort to arrive at a more integrative assessment of densification scenarios.

\section{Acknowledgments}

This study was realised within the project "Future green city" with financial support from the Federal Ministry of Education and Research (Germany). Special thanks are due to the urban planners at the city of Munich that provided information and insights into their working routines.

\section{Conflict of Interests}

The authors declare no conflict of interests.

\section{Supplementary Material}

Supplementary material for this article is available online in the format provided by the author (unedited). 


\section{References}

Acero, J. A., \& Arrizabalaga, J. (2018). Evaluating the performance of ENVI-met model in diurnal cycles for different meteorological conditions. Theoretical and Applied Climatology, 131(1-2), 455-469. https://doi. org/10.1007/s00704-016-1971-y

Akbari, H., \& Kolokotsa, D. (2016). Three decades of urban heat islands and mitigation technologies research. Energy and Buildings, 133, 834-842. https://doi.org/10.1016/j.enbuild.2016.09.067

Ali-Toudert, F., \& Mayer, H. (2006). Numerical study on the effects of aspect ratio and orientation of an urban street canyon on outdoor thermal comfort in hot and dry climate. Building and Environment, 41(2), 94-108. https://doi.org/10.1016/j.buildenv.2005.01.013

Ali-Toudert, F., \& Mayer, H. (2007). Thermal comfort in an east-west oriented street canyon in Freiburg (Germany) under hot summer conditions. Theoretical and Applied Climatology, 87(1/4), 223-237. https://doi. org/10.1007/s00704-005-0194-4

Artmann, M., Inostroza, L., \& Fan, P. (2019). Urban sprawl, compact urban development and green cities. How much do we know, how much do we agree? Ecological Indicators, 96, 3-9. https://doi.org/10.1016/ j.ecolind.2018.10.059

Bande, L., Afshari, A., Al Masri, D., Jha, M., Norford, L., Tsoupos, A., . . A Armstrong, P. (2019). Validation of UWG and ENVI-met models in an Abu Dhabi District, based on site measurements. Sustainability, 11(16). https://doi.org/10.3390/su11164378

Bayerische Staatskanzlei. (2020). Bayerische Bauordnung (BayBO) in der Fassung der Bekanntmachung vom 14. August 2007 [Bavarian building regulation in the version of the announcement of $14^{\text {th }}$ August 2007] (GVBI. S. 588, BayRS 2132-1-B). Munich: Bayerische Staatskanzlei.

Bowler, D. E., Buyung-Ali, L., Knight, T. M., \& Pullin, A. S. (2010). Urban greening to cool towns and cities: A systematic review of the empirical evidence. Landscape and Urban Planning, 97(3), 147-155. https://doi.org/ 10.1016/j.landurbplan.2010.05.006

Bruse, M., \& Fleer, H. (1998). Simulating surfaceplant-air interactions inside urban environments with a three dimensional numerical model. Environmental Modelling \& Software, 13(3/4), 373-384. https://doi.org/10.1016/S1364-8152(98)00042-5

Chatzidimitriou, A., \& Axarli, K. (2017). Street canyon geometry effects on microclimate and comfort; a case study in Thessaloniki. Procedia Environmental Sciences, 38, 643-650. https://doi.org/10.1016/ j.proenv.2017.03.144

Chatzidimitriou, A., \& Yannas, S. (2016). Microclimate design for open spaces: Ranking urban design effects on pedestrian thermal comfort in summer. Sustainable Cities and Society, 26, 27-47. https://doi.org/ 10.1016/j.scs.2016.05.004

Deilami, K., Kamruzzaman, M., \& Liu, Y. (2018). Urban heat island effect: A systematic review of spatiotemporal factors, data, methods, and mitigation measures. International Journal of Applied Earth Observation and Geoinformation, 67, 30-42. https://doi.org/ 10.1016/j.jag.2017.12.009

Demuzere, M., Orru, K., Heidrich, O., Olazabal, E., Geneletti, D., Orru, H., . . . Faehnle, M. (2014). Mitigating and adapting to climate change: Multifunctional and multi-scale assessment of green urban infrastructure. Journal of Environmental Management, 146, 107-115. https://doi.org/10.1016/ j.jenvman.2014.07.025

Emmanuel, R., \& Steemers, K. (2018). Connecting the realms of urban form, density and microclimate. Building Research \& Information, 46(8), 804-808. https://doi.org/10.1080/09613218.2018.1507078

Erell, E. (2017). Urban greening and microclimate modification. In P. Y. Tan \& C. Y. Jim (Eds.), Greening cities (pp. 73-94). Singapore: Springer Singapore. https:// doi.org/10.1007/978-981-10-4113-6_4

Erell, E., Pearlmutter, D., \& Williamson, T. (2011). Urban microclimate: Designing the spaces between buildings. London: Earthscan.

European Commission. (2016). Assessing adaptation knowledge in Europe: Ecosystem-based adaptation (Project No. DESNL16057). Brussels: European Commission. Retrieved from https://ec.europa.eu/ clima/sites/clima/files/adaptation/what/docs/ ecosystem_based_adaptation_en.pdf

German Meteorological Service. (2018). Vieljährige Stationsmittelwerte für die Klimareferenzperiode 1981-2010, für aktuellen Standort und Bezugsstandort: Stations-ID 3379 Muenchen-Stadt [Multi-year station mean values for the climate reference period 1981-2010, for current location and reference site: Station ID 3379 Munich city]. DWD. Retrieved from https://opendata.dwd.de/climate_environment/ CDC/observations_germany/climate/multi_annual/ mean_81-10

Haaland, C., \& van den Bosch, C. K. (2015). Challenges and strategies for urban green-space planning in cities undergoing densification: A review. Urban Forestry \& Urban Greening, 14(4), 760-771.

Hansen, R., \& Pauleit, S. (2014). From multifunctionality to multiple ecosystem services? A conceptual framework for multifunctionality in green infrastructure planning for urban areas. Ambio, 43(4), 516-529.

Hirashima, S. Q. d. S., Katzschner, A., Ferreira, D. G., Assis, E. S. d., \& Katzschner, L. (2018). Thermal comfort comparison and evaluation in different climates. Urban Climate, 23, 219-230. https://doi.org/ 10.1016/j.uclim.2016.08.007

Holst, J., \& Mayer, H. (2010). Urban humanbiometeorology: Investigations in Freiburg (Germany) on human thermal comfort. Urban Climate News, 38, 5-10.

Holst, J., \& Mayer, H. (2011). Impacts of street design parameters on human-biometeorological variables. 
Meteorologische Zeitschrift, 20(5), 541-552. https:// doi.org/10.1127/0941-2948/2011/0254

Jamei, E., \& Rajagopalan, P. (2018). Effect of street design on pedestrian thermal comfort. Architectural Science Review, 28(455), 1-20. https://doi.org/ 10.1080/00038628.2018.1537236

Jamei, E., Rajagopalan, P., Seyedmahmoudian, M., \& Jamei, Y. (2016). Review on the impact of urban geometry and pedestrian level greening on outdoor thermal comfort. Renewable and Sustainable Energy Reviews, 54, 1002-1017. https://doi.org/10.1016/ j.rser.2015.10.104

Konarska, J., Lindberg, F., Larsson, A., Thorsson, S., \& Holmer, B. (2014). Transmissivity of solar radiation through crowns of single urban trees: Application for outdoor thermal comfort modelling. Theoretical and Applied Climatology, 117(3/4), 363-376. https://doi. org/10.1007/s00704-013-1000-3

Landeshauptstadt München. (2011). Langfristige Siedlungsentwicklung: Kongressinformation [Long term settlement development: Congress information]. Munich: Landeshauptstadt München. Retrieved from https://www.muenchen.de/rathaus/ Stadtverwaltung/Referat-fuer-Stadtplanungund-Bauordnung/Projekte/LangfristigeSiedlungsentwicklung/Projekt/Verdichtung.html

Landeshauptstadt München. (2020). Mobilitätskonzept [Mobility concept]. Landeshauptstadt München. Retrieved from https://www.muenchen.de/rathaus/ Stadtverwaltung/Referat-fuer-Stadtplanung-undBauordnung/Lokalbaukommission/Kundeninfo/ Mobilitaetskonzept.html

Lee, H., \& Mayer, H. (2018). Maximum extent of human heat stress reduction on building areas due to urban greening. Urban Forestry \& Urban Greening, 32, 154-167.

Lee, H., Mayer, H., \& Chen, L. (2016). Contribution of trees and grasslands to the mitigation of human heat stress in a residential district of Freiburg, Southwest Germany. Landscape and Urban Planning, 148, 37-50. https://doi.org/10.1016/j.landurbplan.2015. 12.004

Lee, H., Mayer, H., \& Kuttler, W. (2020). Impact of the spacing between tree crowns on the mitigation of daytime heat stress for pedestrians inside $\mathrm{E}-\mathrm{W}$ urban street canyons under Central European conditions. Urban Forestry \& Urban Greening, 48. https://doi. org/10.1016/j.ufug.2019.126558

Mayer, H., \& Höppe, P. (1987). Thermal comfort of man in different urban environments. Theoretical and Applied Climatology, 38(1), 43-49. https://doi.org/ 10.1007/BF00866252

Moser, A., Rötzer, T., Pauleit, S., \& Pretzsch, H. (2015). Structure and ecosystem services of small-leaved lime (Tilia cordata Mill.) and black locust (Robinia pseudoacacia L.) in urban environments. Urban Forestry \& Urban Greening, 14(4), 1110-1121. https://doi.org/10.1016/j.ufug.2015.10.005
Mühlbacher, G., Koßmann, M., Sedlmaier, K., \& Winderlich, K. (2020). Stadtklimatische Untersuchungen der sommerlichen Temperaturverhältnisse und des Tagesgangs des Regionalwindes ("Alpines Pumpen") in München. Berichte des Deutschen Wetterdienstes: Vol. 252 [Urban climatic studies of summer temperature conditions and the diurnal cycle of the regional wind ("Alpine Pumping") in Munich. Reports of the German Weather Service: Vol. 252]. Offenbach: Deutscher Wetterdienst.

Oke, T. R. (1982). The energetic basis of the urban heat island. Quarterly Journal of the Royal Meteorological Society, 108(455), 1-24. https://doi.org/10.1002/ qj.49710845502

Pacifici, M., Marins, K. R. d. C., Catto, V. d. M., Rama, F., \& Lamour, Q. (2017). Morphological and climate balance: Proposal for a method to analyze neighborhood urban forms by way of densification. Sustainable Cities and Society, 35, 145-156. https://doi.org/ 10.1016/j.scs.2017.07.023

Pauleit, S., \& Duhme, F. (2000). Assessing the environmental performance of land cover types for urban planning. Landscape and Urban Planning, 52(1), 1-20. https://doi.org/10.1016/S01692046(00)00109-2

Perini, K., \& Magliocco, A. (2014). Effects of vegetation, urban density, building height, and atmospheric conditions on local temperatures and thermal comfort. Urban Forestry \& Urban Greening, 13(3), 495-506. https://doi.org/10.1016/j.ufug.2014.03.003

Rahman, M. A., Hartmann, C., Moser-Reischl, A., Strachwitz, M. F., von Paeth, H., Pretzsch, H., . . Rötzer, T. (2020). Tree cooling effects and human thermal comfort under contrasting species and sites. Agricultural and Forest Meteorology, 287. https://doi.org/ 10.1016/j.agrformet.2020.107947

Rahman, M. A., Moser, A., Rötzer, T., \& Pauleit, S. (2019). Comparing the transpirational and shading effects of two contrasting urban tree species. Urban Ecosystems, 22(4), 683-697. https://doi.org/ 10.1007/s11252-019-00853-x

Rahman, M. A., Stratopoulos, L. M. F., Moser-Reischl, A., Zölch, T., Häberle, K.-H., Rötzer, T., . . . Pauleit, S. (2020). Traits of trees for cooling urban heat islands: A meta-analysis. Building and Environment, 170. https://doi.org/10.1016/j.buildenv.2019.106606

Sanusi, R., Johnstone, D., May, P., \& Livesley, S. J. (2016). Street orientation and side of the street greatly influence the microclimatic benefits street trees can provide in summer. Journal of Environmental Quality, 45(1), 167-174. https://doi.org/10.2134/jeq2015.01. 0039

Simon, H. (2016). Modeling urban microclimate: Development, implementation and evaluation of new and improved calculation methods for the urban microclimate model ENVI-met (Doctoral dissertation). Johannes Gutenberg-University, Mainz. Retrieved from https://openscience.ub.uni-mainz.de/handle/ 
20.500.12030/4044

Simon, H., Linden, J., Hoffmann, D., Braun, P., Bruse, M., \& Esper, J. (2018). Modeling transpiration and leaf temperature of urban trees: A case study evaluating the microclimate model ENVI-met against measurement data. Landscape and Urban Planning, 174, 33-40. https://doi.org/10.1016/j.landurbplan.2018. 03.003

Sjöman, J. D., Hirons, A., \& Sjöman, H. (2016). Branch area index of solitary trees: Understanding its significance in regulating ecosystem services. Journal of Environmental Quality, 45(1), 175-187. https://doi. org/10.2134/jeq2015.02.0069

Staiger, H., Laschewski, G., \& Matzarakis, A. (2019). Selection of Appropriate thermal indices for applications in human biometeorological studies. Atmosphere, 10. https://doi.org/10.3390/atmos10010018

Stevenson, M., Thompson, J., Sá, T. H. d., Ewing, R., Mohan, D., McClure, R., . . . Woodcock, J. (2016). Land use, transport, and population health: estimating the health benefits of compact cities. The Lancet, 388, 2925-2935. https://doi.org/10.1016/S01406736(16)30067-8

Stewart, I. D., \& Oke, T. R. (2012). Local climate zones for urban temperature studies. Bulletin of the American Meteorological Society, 93(12), 1879-1900. https:// doi.org/10.1175/BAMS-D-11-00019.1

Tsoka, S., Tsikaloudaki, A., \& Theodosiou, T. (2018). Analyzing the ENVI-met microclimate model's performance and assessing cool materials and urban vegetation applications: A review. Sustainable Cities and Society, 43, 55-76. https://doi.org/10.1016/j.scs. 2018.08.009

\section{About the Authors}

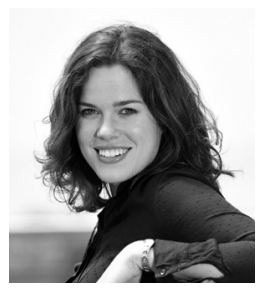

Sabrina Erlwein is a PhD Candidate at the Chair for Strategic Landscape Planning and Management at the Technical University of Munich. She has studied Geography and Environmental Planning in Marburg, Utrecht and Munich and has work experience as a city planner. Her research interest lies in investigating the possibilities of adapting the climate of growing cities through urban greenery and in interdisciplinary city planning.

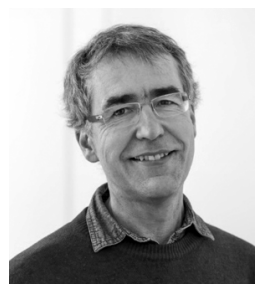

Stephan Pauleit is Professor in Strategic Landscape Planning and Management at the Technical University of Munich. He has developed a special interest in research to advance urban green infrastructure planning and multifunctional nature-based solutions in the urban environment, particularly urban forests and trees. At present, Stephan Pauleit is the Director of the "Centre for Urban Ecology and Climate Change Adaptation," awarded by the Bavarian State Ministry of the Environment and Consumer Protection. 